\title{
Misinterpretation of Achalasia as a Pneumothorax in Transthoracic Ultrasonography
}

Transtorasik ultrasonografide akalazyanın pnömotoraks olarak yanlış yorumlanması

Amirhosein Jahanshir, Hojat Sheikh Motahar Vahedi, Javad Seyed Hosseini, Maryam Bahreini

Department of Emergency Medicine, Tehran University of Medical Sciences, Tehran, Iran

\section{ABSTRACT}

Introduction: Evaluation of a suspected pneumothorax by ultrasonography is a routine procedure in emergency departments. Ultrasonography is highly sensitive for the detection of a pneumothorax and yet has some false-positive results.

Case Report: In this case report, we present a 60-year-old man with achalasia that was misinterpreted as a pneumothorax in routine bedside thoracic ultrasonography.

Conclusion: Achalasia is a rare cause of false-positive reports of pneumothorax by bedside ultrasonography.

Keywords: Pneumothorax, achalasia, ultrasonography

Received: 27.07.2014 Accepted: 27.08.2014

\section{ÖZET}

Giriş: Şüpheli pnömotoraksın ultrasonografi ile değerlendirilmesi acil servis bölümlerinde yapılan rutin bir işlemdir. Ultrasonografi pnömotoraksın tespit edilmesinde oldukça duyarlıdır, ancak bazı yanlış-pozitif sonuçlar vermektedir.

Olgu sunumu: Bu olgu sunumunda, rutin yatak başı torasik ultrasonografide pnömotoraks olarak yanlış değerlendirilen akalazyası olan 60 yaşındaki bir erkek hastayı sunmaktayız.

Sonuç: Akalazya, pnömotoraksın yatak başı ultrasonografi ile elde edilen yanlış-pozitif sonuçlarının nadir bir nedenidir.

Anahtar Kelimeler: Pnömotoraks; akalazya; ultrasonografi

Geliş Tarihi: 27.07.2014 Kabul Tarihi: 27.08.2014

\section{Introduction}

Detection of pneumothorax by bedside ultrasonography is a routine procedure in emergency departments. The "barcode or stratosphere sign" in M-mode and "lung point" in B-Mode are important signs of pneumothorax in ultrasonography, and "lung point" is considered pathognomonic. In this case report, we present achalasia as another diagnosis that may produce a barcode sign and be misinterpreted as pneumothorax in transthoracic ultrasonography with a linear high-frequency probe.

\section{Case Report}

A 60-year-old man visited our emergency department with shortness of breath as his chief complaint. He had previous episodes of massive pleural effusion of unknown origin, which had been treated by pleurodesis. His vital signs in the triage room were: $\mathrm{BP}=140 / 80 \mathrm{~mm} \mathrm{Hg}, \mathrm{HR}=104$ beats per minute, $\mathrm{RR}=36$ breaths per minute, temperature $38.2^{\circ} \mathrm{C}$, and $\mathrm{O}_{2} \mathrm{Sat}=75 \%$ in room air that increased to $94 \%$ with nasal oxygen.

He was triaged to our resuscitation room. He had diminished breath sounds in his right hemithorax. According to our clinical findings and his past medical history, massive parapneumonic pleural effusion or empyema was our primary diagnosis, and we performed a focused ultrasound assessment to rapidly recognize if there was any pleural effusion. Our assessment was positive for pleural effusion, but surprisingly, in M-mode ultrasound, we found typical signs of pneumothorax: a barcode sign on the patient's right hemithorax and a lung point on midclavicular line. Since the clinical diagnosis was not a tension pneumothorax, we obtained a chest $\mathrm{x}$-ray. In his chest $\mathrm{x}$-ray, there was a lucent area extending from the sternal notch to the superior aspect of the heart that looked like an intestinal loop at first glance, suggesting diaphragmatic hernia (Figs 1 and 2). When we asked the 


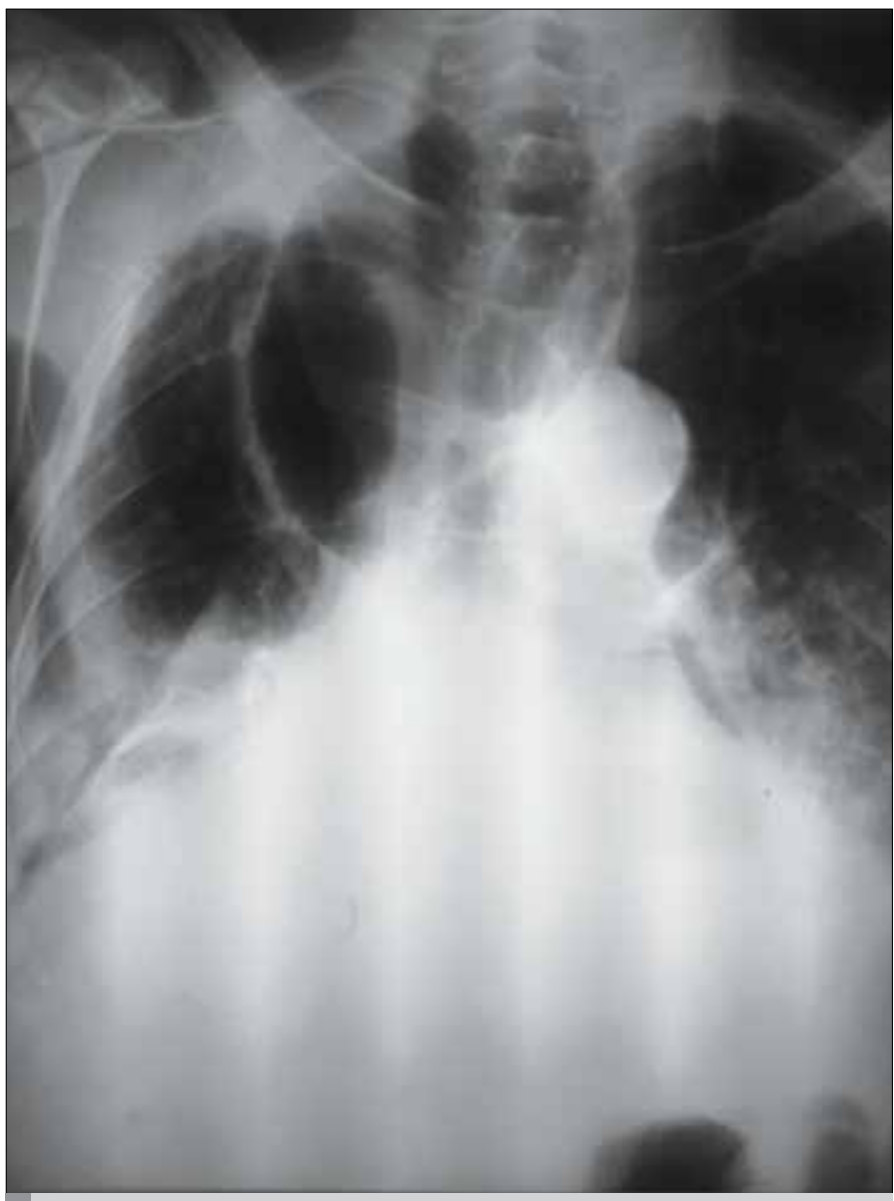

Figure 1. The patient's chest $\mathrm{x}$-ray before chest tube placement

patient about any previous gastrointestinal problems, he stated that he was diagnosed with achalasia previously but he did not think that it was important to tell us.

Because the risk of iatrogenic pneumothorax during pleurocentesis in a patient who has been treated previously with pleurodesis is high, we decided to admit the patient to the surgical ward for further investigation. Our thoracic surgeon placed a chest tube in the patient's left side hemithorax and subsequently started intravenous antibiotics for empyema. After 7 days in the ward, the patient was well enough to be discharged, and the surgeon referred him for outpatient gastroenterology consultation.

\section{Discussion}

Detection of pneumothorax by bedside ultrasonography is a routine and valuable procedure in emergency and critical care departments $(1,2)$. Compared with supine chest $x$-ray, which has a sensitivity of $36 \%-75 \%$ in detecting pneumothorax, ultrasonography has a sensitivity of $92 \%-100 \%(3,4)$. The signs of pneumothorax in B-mode ultrasound are "absence of pleural sliding," "absence of comet tail," and "lung point." "Lung point" is where normal soft tissue of the lung meets the pneumothorax in the pleural space and has been considered a pathognomonic sign of a pneumothorax [5]. In a supine patient with a small pneumothorax, the "lung point" will be

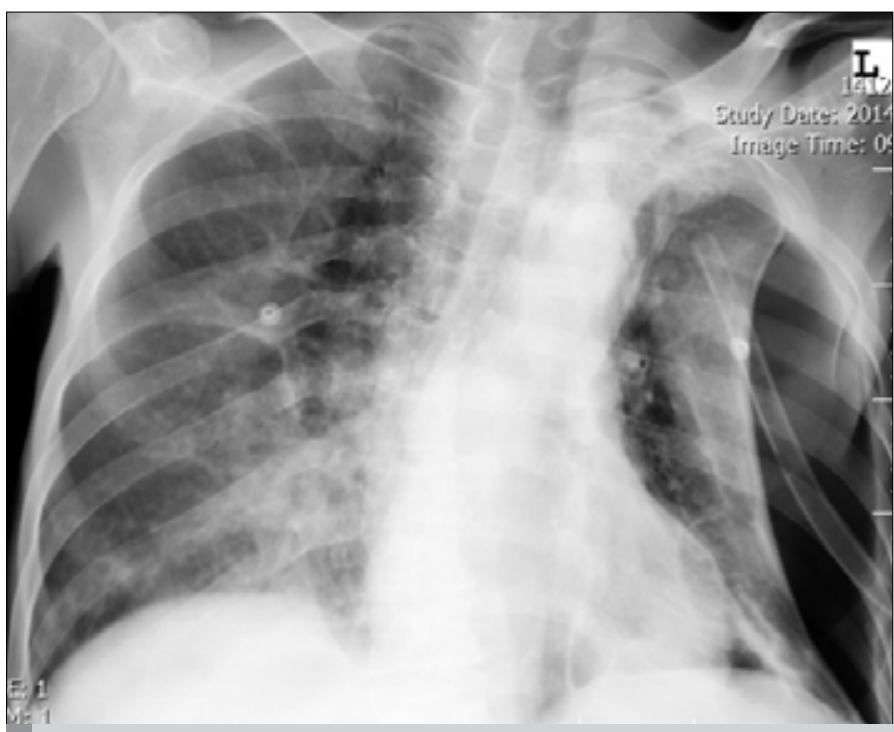

Figure 2. The patient's chest $\mathrm{x}$-ray after chest tube placement

located anteriorly, while in a larger pneumothorax, it will be more lateral. If the operator has limited experience, he may misinterpret the transition line between the lung and pericardium or pleural effusion as the "lung point" (1).

In M-mode ultrasonography, normal lung motion is displayed as a "seashore sign." The change of appearance between the lung and overlying soft tissue resembles that between sea waves and shore sand. In the presence of a pneumothorax, the resulting lack of motion is displayed as horizontal lines and is called a "barcode or stratosphere sign" (2).

Ultrasonography is rarely used for the evaluation of thoracic esophagus (6). Because the esophagus has a posterior location related to the lung and trachea, we do not expect to see it in transthoracic ultrasonography with a linear high-frequency probe. Transthoracic ultrasound is not a routine imaging modality for diagnosing achalasia. Some have suggested endoluminal and endoscopic ultrasonography for this purpose (7-9). In this case report, we presented a case of achalasia that had been misinterpreted as a pneumothorax, because an air-filled esophagus had produced a barcode sign and lung point on transthoracic ultrasonography with a linear high-frequency probe.

\section{Conclusion}

It is possible for a large achalasia to change its position and come more anteriorly, as visualized on transthoracic ultrasonography. Achalasia may be large enough to produce ultrasonographic images that may be misinterpreted as a barcode sign and lung point, which are classic signs of pneumothorax in routine ultrasonography and eFAST exam.

Informed Consent: Informed consent was obtained from patient who participated in this case. 
Peer-review: Externally peer-reviewed.

Author Contributions: Concept - A.J., M.B.; Design - M.B., H.S.M.V.; Supervision - A.J., M.B.; Materials - H.S.M.V., J.S.H.; Analysis and/or Interpretation - A.J., H.S.M.V.; Literature Review - A.J., H.S.M.V.; Writer - A.J.; Critical Review - A.J., M.B .

Conflict of Interest: The authors declared no conflict of interest.

Financial Disclosure: The authors declared that this study has received no financial support.

Hasta Onamı: Hasta onamı bu olguya katılan hastadan alınmıştır.

Hakem Değerlendirmesi: Dış bağımsız.

Yazar Katkıları: Fikir - A.J., M.B.; Tasarım - M.B., H.S.M.V.; Denetleme - A.J., M.B.; Malzemeler - H.S.M.V., J.S.H .; Analiz ve/veya yorum - A.J., H.S.M.V.; Literatür taraması - A.J., H.S.M.V.; Yazıyı yazan - A.J.; Eleştirel inceleme - A.J., M.B.

Çıkar Çatışması: Yazarlar çıkar çatışması bildirmemişlerdir.

Finansal Destek: Yazarlar bu çalışma için finansal destek almadıklarını beyan etmişlerdir.

\section{References}

1. Husain LF, Hagopian L, Wayman D, Baker WE, Carmody KA. Sonographic diagnosis of pneumothorax. J Emerg Trauma Shock 2012; 5: 76-81. [CrossRef]

2. Ouellet JF, Ball CG, Panebianco NL, Kirkpatrick AW. The sonographic diagnosis of pneumothorax. J Emerg Trauma Shock 2011; 4: 504-7.

3. Blaivas M, Lyon M, Duggal S. A prospective comparison of supine chest radiography and bedside ultrasound for the diagnosis of traumatic pneumothorax. Acad Emerg Med 2005; 12: 844-9. [CrossRef]

4. Soldati G, Testa A, Sher S, Pignataro G, La Sala M, Silveri NG. Occult traumatic pneumothorax: diagnostic accuracy of lung ultrasonography in the emergency department. Chest 2008; 133: 204-11. [CrossRef]

5. Lichtenstein D. Lung ultrasound in the critically ill. Current opinion in critical care 2014; 20: 315-22. [CrossRef]

6. Zhu SY, Liu RC, Chen LH, Luo F, Yang H, Feng $X$, et al. Sonographic demonstration of the normal thoracic esophagus. Journal of clinical ultrasound: JCU 2005; 33: 29-33.[CrossRef]

7. Miller LS, Liu JB, Barbarevech CA, Baranowski RJ, Dhuria M, Schiano TD, et al. High-resolution endoluminal sonography in achalasia. Gastrointestinal endoscopy 1995; 42: 545-9. [CrossRef]

8. Chambon J, Gaudric M, Amouyal P, Chaussade S, Chapuis Y, Louvel A, et al. [Achalasia associated with gastric leiomyoma. The value of endoscopic sonography]. Gastroenterol clin biol 1990; 14: 605-7.

9. Ohtsuki J. [Utility of endoscopic ultra-sonography for esophageal achalasia]. J smooth muscle res 1995; 31: 5-13. [CrossRef] 